at a large prairie lake and wetland complex: the Quill Lakes, Saskatchewan. Occasional Paper No. 97, Canadian Wildlife Service, Environment Canada, Ottawa, ON. 47 pp.

2. COLWELL, M. A. 1987. Seasonal shorebird abundance at Last Mountain Lake Wildlife Management Unit. Blue Jay 45:251266.

3. DONALDSON, G. M., C. HYSLOP, R. I. G. MORRISON, H. L. DICKSON, I. DAVIDSON. 2000. Canadian Shorebird Conservation Plan. Canadian Wildlife Service, Environment Canada, Ottawa, ON. 27 pp.
4. ROY, J. F. 1996, Birds of the Elbow. Special Publication No. 21, Saskatchewan Natural History Society, Regina, SK. 325 pp.

5. SKAGEN, S. K., P. B. SHARPE, R. G. WALTERMIRE, M. B. DILLON. 1999. Biogeographical profiles of shorebird migration in midcontinental North America. U. S. Geological Service Biological Science Report USGS/BRD/BSR-2000-0003.

6. SMITH, A. R. 1996. Atlas of Saskatchewan Birds. Special Publication No. 22, Saskatchewan Natural History Society, Regina, SK. 456 pp.

\title{
THREE TURKEY VULTURE PAIRS NEST IN SASKATOON BIRD AREA
}

C. STUART HOUSTON, 863 University Drive, Saskatoon, SK S7N 0J8, MARTEN J. STOFFEL, Box 183, RR\#4, Saskatoon, SK S7K 3J7, and ALAN R. SMITH, Canadian Wildlife Service, 115 Perimeter Road, Saskatoon, SK S7N 0X4

Turkey Vultures were regularly seen on the treeless plains while bison were present, and until at least $1890 .{ }^{4}$ They appeared in the Cypress Hills and Big Muddy badlands, along the Qu'Appelle and North and South Saskatchewan rivers, near lakes in Moose Mountain and along the southern edge of the boreal forest from Loon Lake to Duck Mountain. The first twelve nests recorded in Saskatchewan were in caves in cliffs or on the ground in nearly impenetrable dense tangles of underbrush. ${ }^{3,7}$ Only since 1983 and 1984 have Saskatchewan vultures been reported nesting, (as they have done in Illinois since $1978,{ }^{2}$ ) in attics of deserted houses, such as one north of Biggar, ${ }^{8}$ one north of Preeceville, ${ }^{1}$ and one west of Turtle Lake (Muriel Carlson, pers. comm.). During 2002, three widely separated pairs, each successful and each on the upper floor of a deserted farmhouse, provided the first definitive proof of Turkey Vultures breeding in the Saskatoon Bird Area (SBA; $51^{\circ} 32^{\prime}$ to $52^{\circ} 30^{\prime}$ north latitude and $106^{\circ}$ to $107^{\circ}$ $30^{\prime}$ west longitude).

On 6 June, Al Smith observed an adult Turkey Vulture on the roof of an abandoned farmhouse $4 \mathrm{~km}$ south and $3.2 \mathrm{~km}$ east of

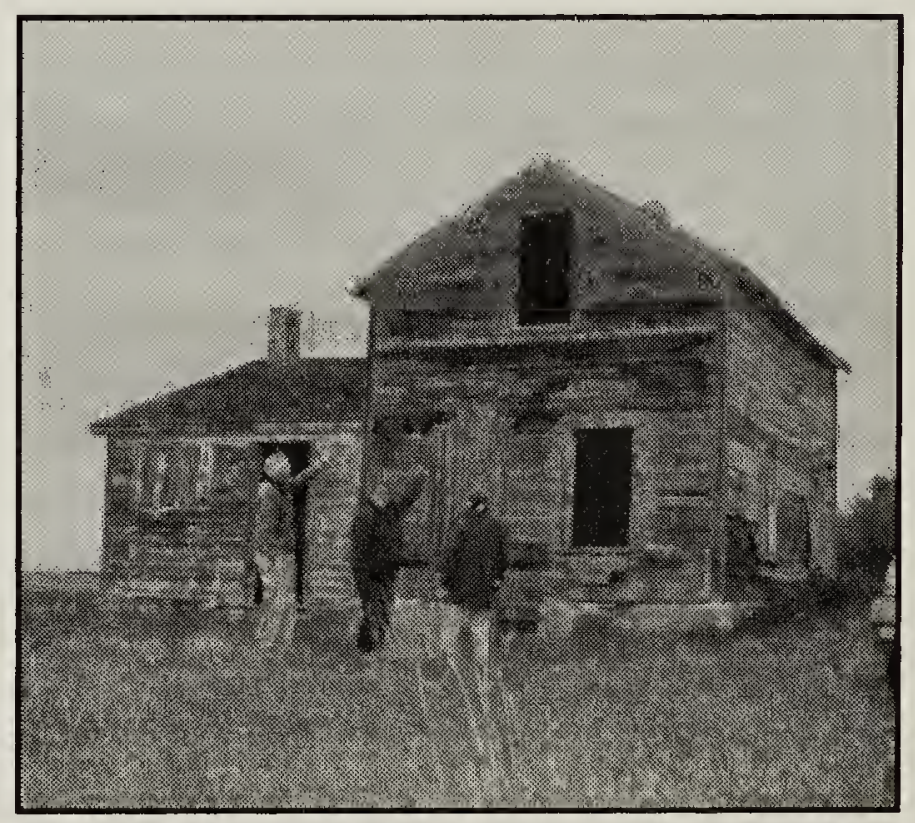

Figure 1. Judy Terry and Stuart pointing to second story window entrance to Turkey Vulture nest near Hanley. Brenton Terry 


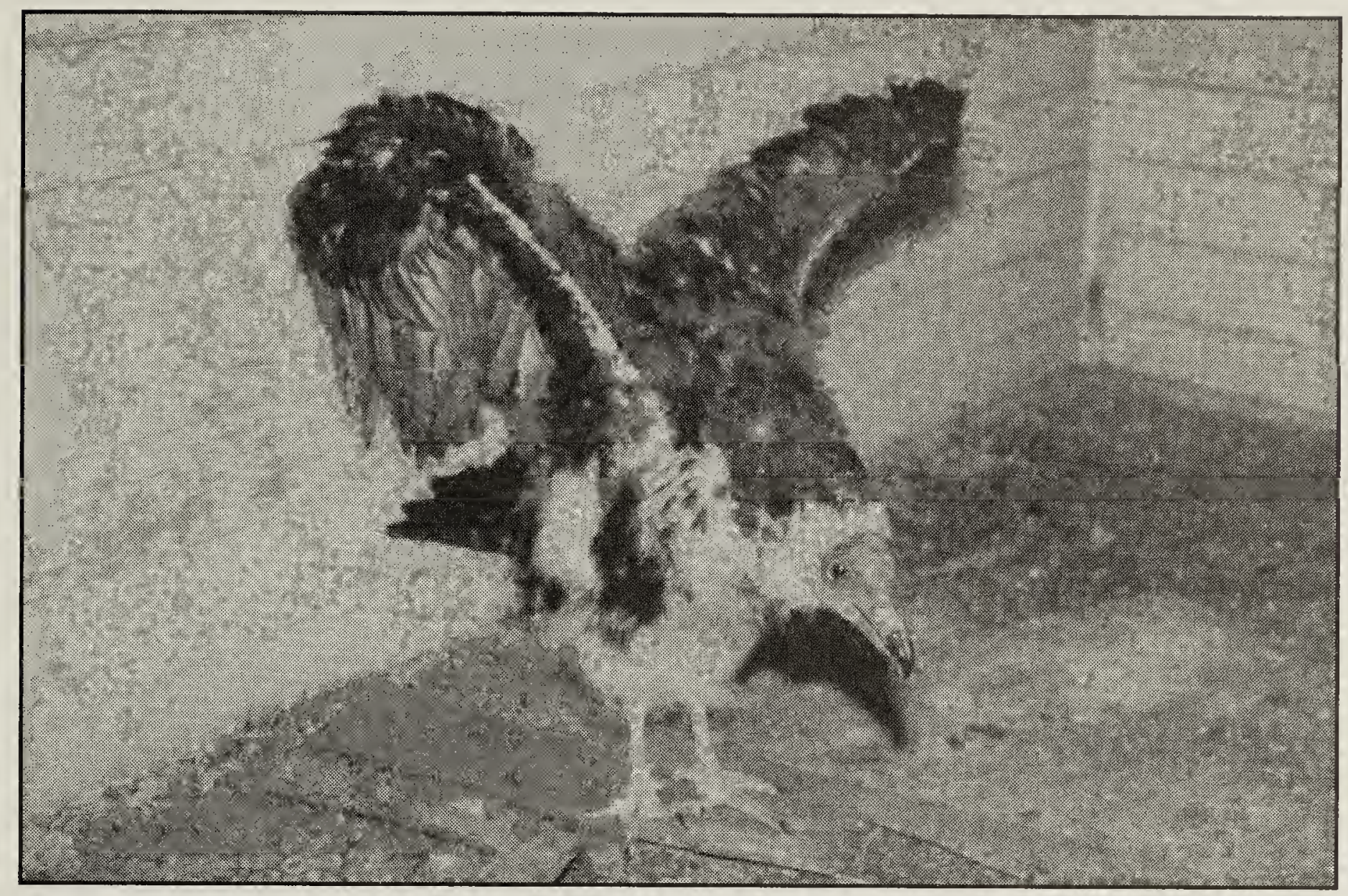

Figure 2. Young Turkey Vulture in defensive posture at the Hanley nest, 4 August 2002.

Brenton Terry

Hanley. On climbing the stairs, he observed the other adult incubating on the floor in a second-storey walk-in closet. The glass had long since disappeared from the upstairs windows. When Stuart and Mary Houston and Brenton and Judy Terry visited this house on 4 August (Figure 1), they went up the stairs to be greeted by two nearly fledged young who were still in the closet. Both young had well-developed primaries, but patches of white down persisted in various places (Figure 2). The young had full plumage when visited on 10 August by $\mathrm{Al}$ and Brenton.

The second nest, in the attic of a shack 2 $\mathrm{km}$ west and $6 \mathrm{~km}$ north of Environ, less than $1 \mathrm{~km}$ east of Eagle Creek valley, had a single fully feathered young on 13 August. This bird was drooling and vomited, perhaps as a defense mechanism. ${ }^{6}$ Farmer Doug Stack reported it to conservation officer Glen Metivier. To rule out the possibility of poisoning, Metivier took the vulture to the small animal clinic at the Veterinary College in Saskatoon for examination. Marten and Moyca Stoffel and
Stuart and Mary returned it to its nest site (Figure 3) on 20 August; it had fledged by 23 August.

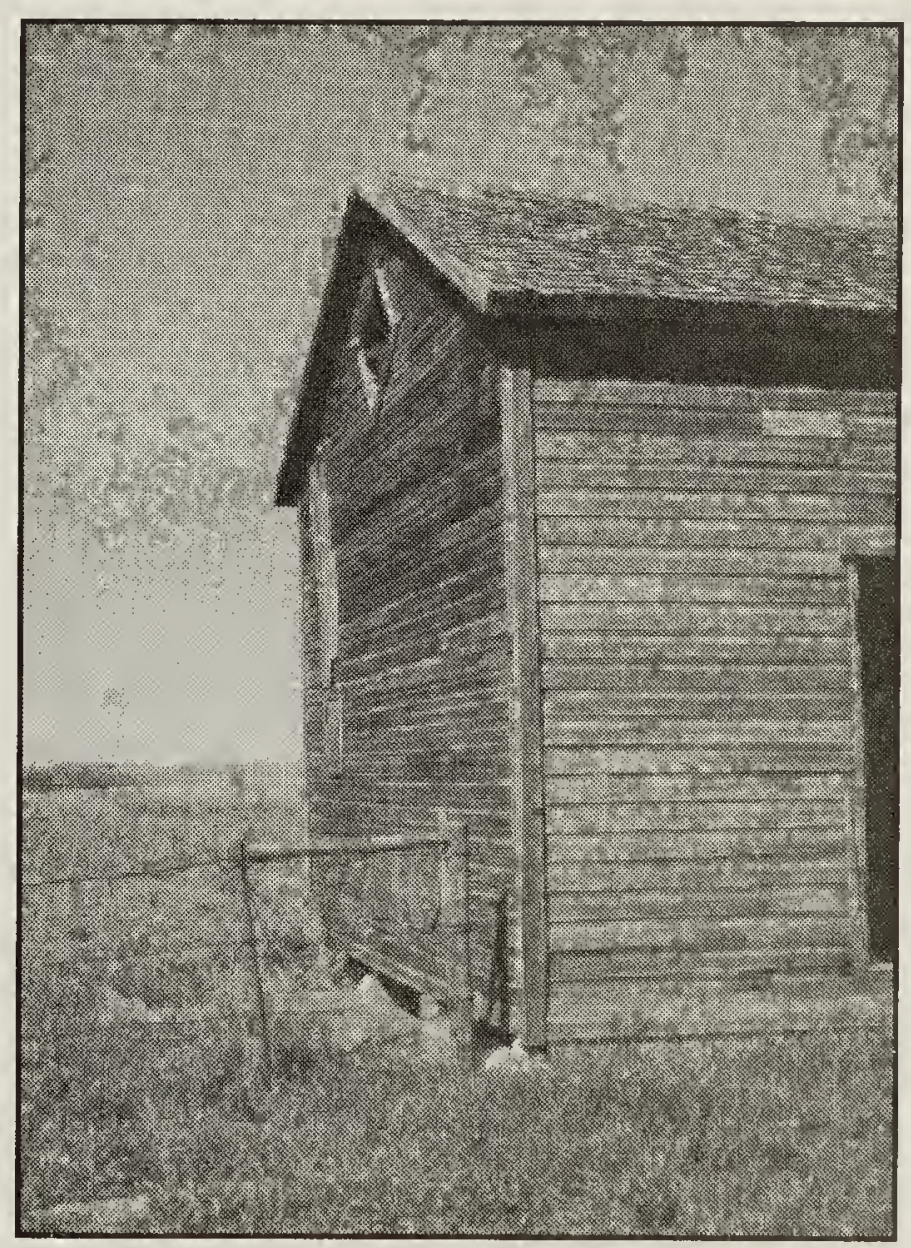

Figure 3. Adult Turkey Vulture in attic window of shack near Environ.

Moyca Stoffel 


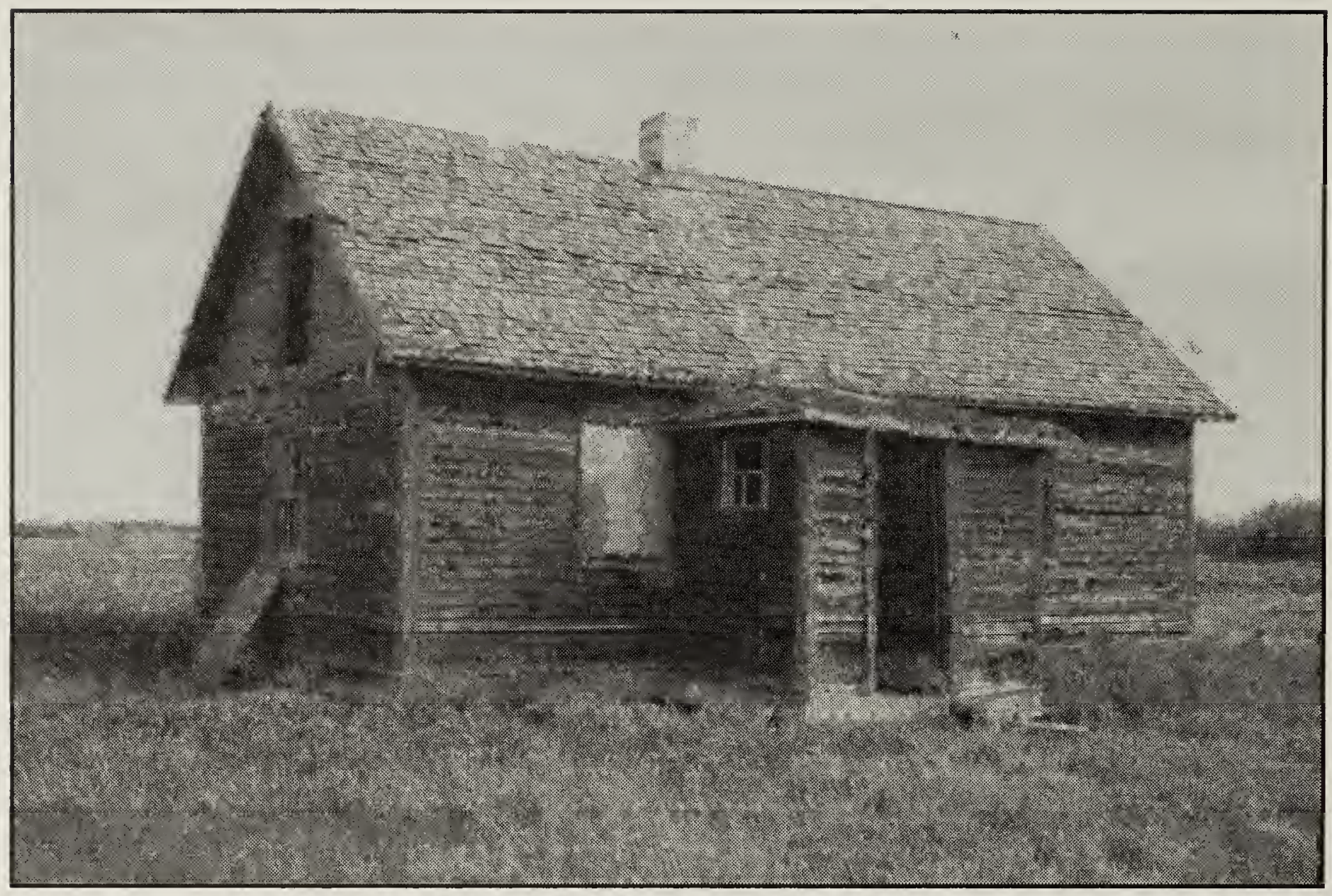

Figure 4. Deserted house location of Turkey Vulture nest near Smuts. Marten Stoffel

The third nest, $5 \mathrm{~km}$ north and $2 \mathrm{~km}$ east of Smuts, was on land farmed by Robert Mantyka, who reported to Yvonne Cuttle that a pair of eagle-sized birds had been nesting in the attic of this deserted house for three or four years. Thus, breeding of Turkey Vultures in the SBA may date back to 1998 or 1999. Cuttle led an excursion of Saskatoon's senior birding group, "The Golden Eagles," to the site on 29 August; two young were flying well. When the site was visited by Stuart and Marten on 3 September (Figure 4), two vultures flew over.

Early in 1999, vultures were seen perched in the window of a deserted farmhouse 11 $\mathrm{km}$ north and $2.5 \mathrm{~km}$ west of Aberdeen, and on 7 June 1999, Lynn Oliphant noted two adults at this location but did not enter the house. Two subsequent visits showed no signs of nesting, but the attic of another house a mile to the southwest, visited on 9 October 2002, showed evidence suggestive of probable vulture occupancy.

After a presumed absence of more than a century from the Saskatoon Bird Area, three
Turkey Vulture pairs bred successfully in 2002 , and raised five young. In a study of 899 Turkey Vulture sites in North America through 1982, a preference for "dark recesses" as nest sites was evident, but only 22 nests were in buildings, chiefly barns. ${ }^{5}$ In Illinois and Saskatchewan, the vultures' predilection for attics, in deserted farm houses whose window glass has long since disappeared, is a relatively recent phenomenon dating to the $1970 \mathrm{~s}$, but perhaps increasing in use. Watch for this, particularly at sites within 15 or $20 \mathrm{~km}$ of a river valley or large lake.

1. BEAULIEU, R. 1985. Abandoned house nest site for Turkey Vulture. Blue Jay 43:4648 .

2. BUHNERKEMPE, J.E., and R.L. WESTEMEIER. 1984. Nest-sites of Turkey Vultures in buildings in southeastern Illinois. Wilson Bulletin 96:495-496.

3. HOUSTON, C.S. 1969. Turkey vulture breeding records in Saskatchewan. Blue Jay 27:37-39. 
4. HOUSTON, C.S., and J.K. SCHMUTZ. 1999. Changes in bird populations on Canadian grasslands. Studies in Avian Biology 19:87-94.

5. JACKSON, J.A. 1983. Nesting phenology, nest site selection and reproductive success of Black and Turkey Vultures, pp. 245-270 In S.R. Wilbur and J.A. Jackson,eds., Vulture Biology and Management. University of California Press, Berkeley.
Birds of North America, No. 339 (A. Poole and F. Gill, eds.). Philadelphia: The Birds of North America, Inc.

7. SMITH, A.R. 1996. Atlas of Saskatchewan Birds. Saskatchewan Natural History Society Special Publication \# 22.

8. WAPPLE, G.J. 1985. Nesting Turkey Vulture near Biggar, Saskatchewan. Blue Jay 43:44-46.

6. KIRK, D.A., and M.J. MOSSMAN. 1998.

Turkey Vulture (Cathartes aura). In The

\title{
A BAD YEAR FOR PURPLE MARTINS NEAR SASKATOON
}

\author{
GERALD J. PARENT, RR\#5, Station Main, Saskatoon SK S7K 3J8, and \\ MARY I. HOUSTON, 863 University Drive, Saskatoon SK S7N 0J8
}

Last year, 2001, was the second year that Purple Martins nested in houses provided for them at the site of the former Grasswood grain elevator south of Saskatoon. It was a particularly successful year: 16 pairs laid 81 eggs (a mean of 5.1 eggs per nest); 75 eggs hatched (93\%) and all 75 nestlings fledged. ${ }^{4}$ We now realize that these figures were as high as or exceeded those previously published in the literature: a mean clutch size of 4.2 to 5.0 and a mean fledging rate of $71 \%$ to $85 \% .^{1}$ Studies near Edmonton in 1965 and 1966 showed that females mated to yearling males had a mean clutch size of 4.29 while females mated to adults had a clutch size of 5.00, and the mean fledging rate was $71 \% .^{2}$

In 2002, the Grasswood colony almost doubled in size, increasing from 16 to 30 active pairs. With 132 eggs laid, the mean clutch size was more typical: 4.4 eggs per nest. Sixteen eggs failed to hatch, bringing the hatching rate down to $88 \%$.
Fourteen nests had adult pairs in attendance; thirteen of these were successful and raised 60 young to banding age (4.6 young per successful adult-pair nest or 4.3 young per nest for all adult pairs). The first three broods, all with adult parents, hatched on June 29, July 3 and July 7 . Fifteen nests had yearling pairs, but one of these pairs abandoned its eggs; 54 young from these nests reached banding age (3.7 young per yearling nest attempt). The only nest with an adult mated to a yearling produced only two young. All 116 young were banded when between 8 and 16 days of age, on July 14, 19, 24, and 29.

For the first time in the three-year life of the colony, nestlings died in the nest boxes. The first nestling died of apparent heat stress on July 25, and two, infested with nest mites, died on July 27. Then unseasonable, record-setting cold weather arrived, with the thermometer plunging to $-2^{\circ} \mathrm{C}$ in the early morning of August 2. All 